\title{
Microbacterium sp. MRS-1, a potential bacterium for cobalt reduction and synthesis of less/non-toxic cobalt oxide nanoparticles $\left(\mathrm{CO}_{3} \mathrm{O}_{4}\right)$
}

Sathyavathi Sundararaju ${ }^{1,2^{*}}$, Manjula Arumugam² ${ }^{2}$ and Prakash Bhuyar ${ }^{3}$

\begin{abstract}
Background: Detoxification of heavy metal pollutants in wastewater has become a serious problem to surrounding environment. This research was conducted to utilize a potential heavy metal-resistant bacterium for the remediation of cobalt metal and simultaneous synthesis of cobalt oxide nanoparticles in the form of powder for various industrial applications. Metal oxide nanoparticles have great applications in electrochemical devices such as supercapacitors, biosensors, and batteries.

Method: A heavy metal-resistant bacterium Microbacterium sp. MRS-1 isolated from electroplating industrial effluent reduced cobalt ions from an initial concentration of $200 \mathrm{mg} / \mathrm{L}$ to $26 \mathrm{mg} / \mathrm{L}$ were analyzed by atomic absorption spectroscopy. Instrumental analysis of bacterially synthesized $\mathrm{CO}_{3} \mathrm{O}_{4}$ has been characterized. Cytotoxicity of synthesized nanoparticles was assessed by MTT assay.

Results: Microbacterium sp. MRS-1 isolated from electroplating industrial effluent was found to be suitable for cobalt oxide nanoparticles as it showed tolerance towards high concentration of metal. The nutrient broth containing metal solution and Microbacterium sp. MRS-1 showed color change from light pink to dark pink indicated the formation of extracellular nanoparticles. It also converted soluble cobalt salts into less soluble cobalt oxide nanoparticles outside the cell which allows easy recovery of nanoparticles without the destruction of cells and simultaneous detoxification of toxic metal ions. Electron microscopic imaging verified that nanoparticles were predominantly surrounding the bacterial cells and SEM imaging revealed that the produced particles were in the range of 10-100 $\mathrm{nm}$ in size. XRD spectrum exhibited $2 \theta$ values were corresponding to cubic face-centered cobalt oxide $\left(\mathrm{CO}_{3} \mathrm{O}_{4}\right)$ nanoparticles.

Conclusion: The present study investigated new prospective for eco-friendly detoxification of toxic heavy metal $\mathrm{Co}$ from metal-polluted sites and the production of cobalt oxide nanoparticles in powder form for clinical and other industrial applications.
\end{abstract}

Keywords: Microbacterium sp. MRS-1, Cobalt reduction, Cobalt oxide nanoparticles $\left(\mathrm{CO}_{3} \mathrm{O}_{4}\right)$, Cytotoxicity assay

\footnotetext{
* Correspondence: sathyasundararaju@gmail.com

'Department of Pathology, Sidra Medicine, Doha, Qatar

${ }^{2}$ Department of Genetics, School of Biological Sciences, Madurai Kamaraj

University, Madurai 625021, India

Full list of author information is available at the end of the article
}

\section{Springer Open}

(c) The Author(s). 2020 Open Access This article is licensed under a Creative Commons Attribution 4.0 International License, which permits use, sharing, adaptation, distribution and reproduction in any medium or format, as long as you give appropriate credit to the original author(s) and the source, provide a link to the Creative Commons licence, and indicate if changes were made. The images or other third party material in this article are included in the article's Creative Commons licence, unless indicated otherwise in a credit line to the material. If material is not included in the article's Creative Commons licence and your intended use is not permitted by statutory regulation or exceeds the permitted use, you will need to obtain permission directly from the copyright holder. To view a copy of this licence, visit http://creativecommons.org/licenses/by/4.0/. 


\section{Introduction}

Metal oxides have interesting physico-chemical, electronic, and optical properties [1]. Therefore, metal oxides such as copper oxide, iron oxides, and cobalt oxides have been extensively synthesized and used in industries such as electroplating, textiles, steelmaking, drug delivery, and as biomedicine [2]. For the multifunctional, antiferromagnetic p-type semiconductor properties, cobalt oxides have been widely used in electrochromic sensors, energy storage, heterogeneous catalysis, pigments, dyes, and in lithium-ion rechargeable batteries as an anode material [3-5]. Like many other heavy metals, cobalt ions present in the wastewater discharged from these industries are of a major concern for the environment. Abatement strategies such as bioremediation showed a promising environmentally friendly approach to address heavy metal contamination. Various chemical and physical methods have been proposed for the synthesis of cobalt oxide nanoparticles, but the conventional methods generate toxic wastes and create secondary pollutants to the environment [6]. In order to overcome the problems of toxic waste generation, plant extracts and microbes can be used in an economical and ecofriendly method for the production of nanoparticles for various applications [7]. Green synthesis of magnetic behavior $\mathrm{CO}_{3} \mathrm{O}_{4}$ nanoparticles by an Aspalathus linearis' leaves natural extract has been reported [5]. Recently, $\mathrm{CO}_{3} \mathrm{O}_{4}$ have been chemically synthesized to develop magnetic semiconductor spintronic devices [8]. Also, cobalt oxide $\left(\mathrm{CoO}, \mathrm{Co}_{3} \mathrm{O}_{4}\right.$, or $\left.\mathrm{Co}_{2} \mathrm{O}_{3}\right)$ is a common component in several pigments [9].

Environments polluted with metals lead to the selection of indigenous metal-resistant microorganism, which can be exploited for the production of useful metal/ metal oxide nanoparticles and also to minimize metal toxicity in the environment [10]. However, the production of cobalt oxide nano powder is considered as a promising technology for a wide range of applications including magnetic resonance imaging contrast agent, anticancer drug delivery system for cancer diagnosis and chemotherapy [11], biosensor properties for DNA genotyping [12], and amino acid detection [13]. The utilization of microorganism for the synthesis of metal/ metal oxide nanoparticles is a natural and eco-friendly process, which represents a promising alternative to the usage of expensive chemical reactants, oxidizing compounds, and its harmful effects $[14,15]$. Heavy metalresistant microorganisms are of great significance in detoxification of soluble toxic inorganic metal ions to insoluble less toxic metal/metal oxide nanoparticles can be made either by extracellular biomineralization, biosorption, complexation or precipitation, or intracellular bioaccumulation [16]. Isolation and screening of heavy metal-resistant bacterial strain resistant to cobalt such as
Staphylococcus aureus, Bacillus subtilis, Bacillus cereus have been reported previously $[17,18]$. Various applications of Microbacterium sp. have been reported in different fields such as bio-emulsifier production and extracellular synthesis of gold, silver, and nickel oxide nanoparticles [16, 19, 20]. Synthesis of hollow cobalt oxide nanoparticles by yeast cells [21] and magnetic cobalt oxide by Brevibacterium casei have been reported recently [22]. As it is well demonstrated that cobaltbased nanoparticles are promising and significant candidates for enormous biomedical applications due to their unique characteristics [23]. In the present study, we report the heavy metal-resistant bacterial strain Microbacterium sp. MRS-1 as a potential candidate for the detoxification of cobalt oxide nanoparticles in the form of $\mathrm{CO}_{3} \mathrm{O}_{4}$ and bioremediation of toxic heavy metals. This study is the first report on the biosynthesis of cobalt oxide nanoparticles $\left(\mathrm{CO}_{3} \mathrm{O}_{4}\right)$ in powder form using Microbacterium sp. MRS-1.

\section{Materials and methods}

\subsection{Bacterial cultivation}

The metal-resistant bacterium, Microbacterium sp. MRS-1 isolated from electroplating industrial effluent showed resistant to cobalt on nutrient agar was taken for this study based on its MIC [16]. It was grown in nutrient broth supplemented with $200 \mathrm{mg} / \mathrm{l}$ of cobalt chloride and incubated at $30{ }^{\circ} \mathrm{C}$ for $120 \mathrm{~h}$ at $180 \mathrm{rpm}$ on the rotary shaker. The culture was centrifuged at $3000 \mathrm{rpm}$ $4{ }^{\circ} \mathrm{C}$ for $10 \mathrm{~min}$. Biomass monitored at every 24 -h interval was recorded by measuring the absorbance at 600 $\mathrm{nm}$ and heavy metal concentration was analyzed using AAS. Each experiment was carried out in triplicate.

\subsection{Biomass characterization}

The extracellular aggregate was collected and washed twice with deionized water by repeated centrifugation steps. UV-DRS (diffused reflection spectra) of the cobalt oxide nanoparticles were recorded using a JASCO-V-550, double beam spectrophotometer with PMT detector. The presence of functional group was identified by FT-IR spectroscopy and morphological studies were carried out using SEM, Hitachi S-4500 microscope operating at $120 \mathrm{kV}$ accelerating voltage attached with EDAX. AFM experiments were carried out by A100SGS atomic force microscope using a Si tip. AFM imaging was done in tapping mode to study the surface morphology. XRD analysis carried out on a PAN analytical-X'pert PRO (PAN analytical, Netherland) and the measurement carried out at $40 \mathrm{kV}$ and 30 $\mathrm{mA}$ in $\mathrm{Cu} \mathrm{KV}$ radiation.

\subsection{Characterization of nanoparticles}

To evaluate the morphology of the cobalt oxide nanoparticles, freshly harvested cobalt treated bacteria were 
washed with $\mathrm{d}_{2} \mathrm{O}$. It was suspended in sterile $\mathrm{d}_{2} \mathrm{O}$ and placed on carbon grid which was then pre-treated with $1 \%$ phosphotungstic acid for $1 \mathrm{~h}$ and pre-treated grid was placed on electron microscope. TEM (model Philips-TACHNAI10, Netherland) equipped with tungsten filament electron source, operated at and $80 \mathrm{kV}$ and Olympus camera has been used for imaging the morphological structure and bacterial interaction of cobalt oxide nanoparticles were imaged. The TGA was carried out using Universal V4.7A thermogravimetric analyser TGA Q50 V20.10 Build 36.

\subsection{MTT assay}

5-diphenyl tetrazolium bromide (MTT) assay was carried out for cytotoxicity, and L929 cells were grown in Dulbecco's modified Eagle's medium (DMEM) supplemented with $10 \%$ fetal bovine serum (FBS), $0.2 \%$ sodium bicarbonate, and antibiotic/antimycotic solution (100×, 1 $\mathrm{mL} / 100 \mathrm{~mL}$ of medium). The cells were maintained in $5 \% \mathrm{CO}_{2}-95 \%$ atmosphere under high humidity at $37{ }^{\circ} \mathrm{C}$. Cells were assessed for cell viability by trypan blue dye exclusion assay as described earlier [24], and batches showing more than $98 \%$ cell viability were used in this study. $\mathrm{L} 929$ cells were treated with different concentrations of $\mathrm{Co}_{3} \mathrm{O}_{4}$-NPs $(50,75$, and $100 \mathrm{mg} / \mathrm{mL})$ for $24 \mathrm{~h}$. After $24 \mathrm{~h}$ of incubation, $10 \mu \mathrm{L}$ of MTT reagent was added to each well and was further incubated for $4 \mathrm{~h}$. Formazan crystals formed after $4 \mathrm{~h}$ in each well were dissolved in $150 \mu \mathrm{L}$ of detergent and the plates were read immediately in a microplate reader (BIO-RAD microplate reader-550) at $570 \mathrm{~nm}$. Wells with complete medium, nanoparticles, and MTT reagent, without cells, were used as blanks. Untreated L929 cells as well as the cell treated with $(50,75$, and $100 \mathrm{mg} / \mathrm{mL})$ concentration of $\mathrm{Co}_{3} \mathrm{O}_{4}$ for $24 \mathrm{~h}$ were subjected to the MTT assay for cell viability determination. The stock solution was then diluted in culture medium to reach the desired concentrations for cell treatment. Approximately $1 \times 10^{5} \mathrm{~mL}^{-1}$ cells (L929) in their exponential growth phase were seeded in a flat-bottomed 96-well polystyrene coated plate and were incubated for $24 \mathrm{~h}$ at $37^{\circ} \mathrm{C}$ in a $5 \% \mathrm{CO}_{2}$ incubator.

\section{Results}

\subsection{Spectroscopy analysis}

In this study, investigation of the bioremediation potential of the Microbacterium sp. MRS-1 to reduce Co (II) ions was carried out. The isolated metal-resistant bacterium Microbacterium sp. reduced $174 \mathrm{mg} / \mathrm{L}$ of cobalt ions from an initial concentration of $200 \mathrm{mg} / \mathrm{L}$ (Fig. 1) and shown here the conversion of soluble cobalt ions into less soluble cobalt oxide nanoparticles outside the cell. The nanoparticles produced extracellularly were deposited on the bottom of the flask and change in medium color to pink was observed. The spectrum obtained from UV-vis spectroscopy (Fig. 2) showed no absorption peak in the control, whereas, the culture exposed to cobalt ions showed distinct broad absorption

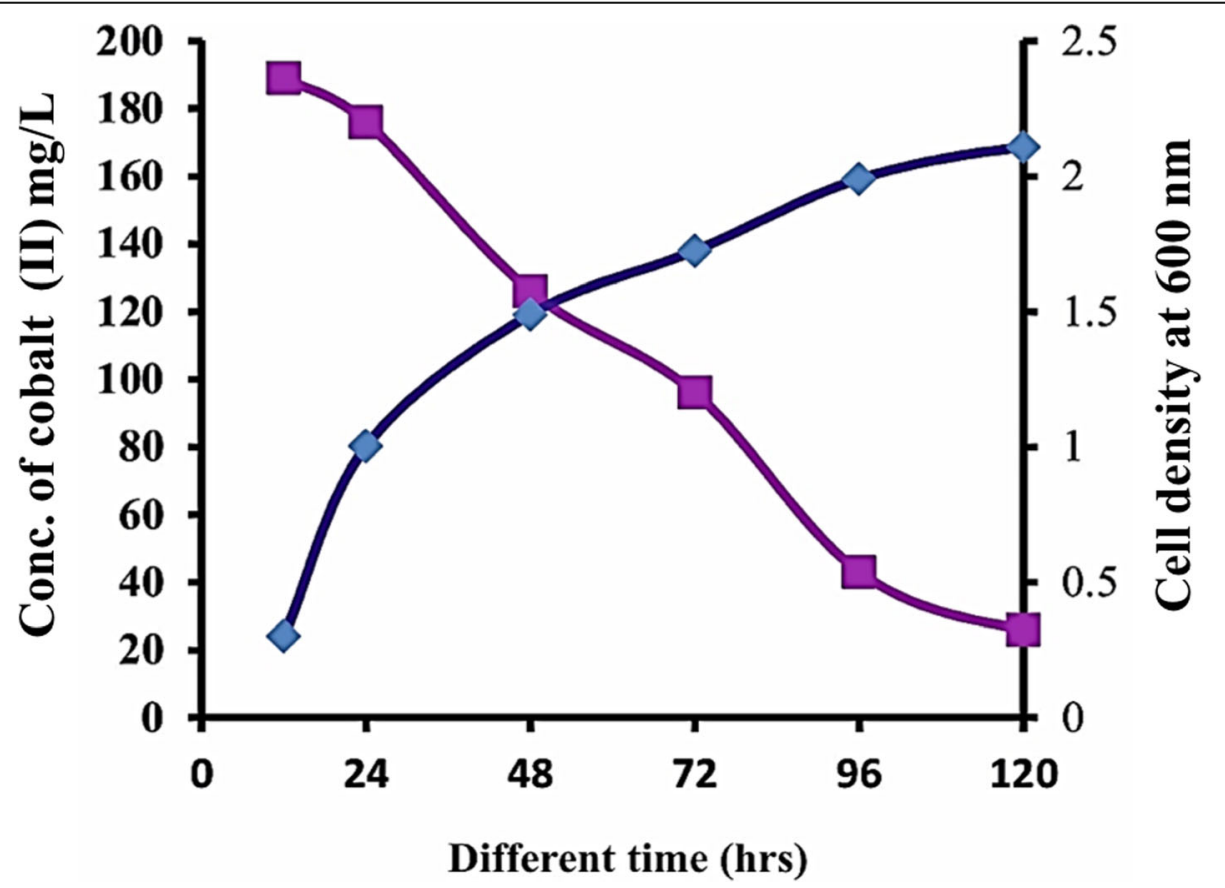

Fig. 1 Growth kinetics and Co removal by Microbacterium sp. MRS-1 at pH 7 and $30^{\circ} \mathrm{C}$. The initial concentration of Co (II) was kept at $200 \mathrm{mg} / \mathrm{L}$ 


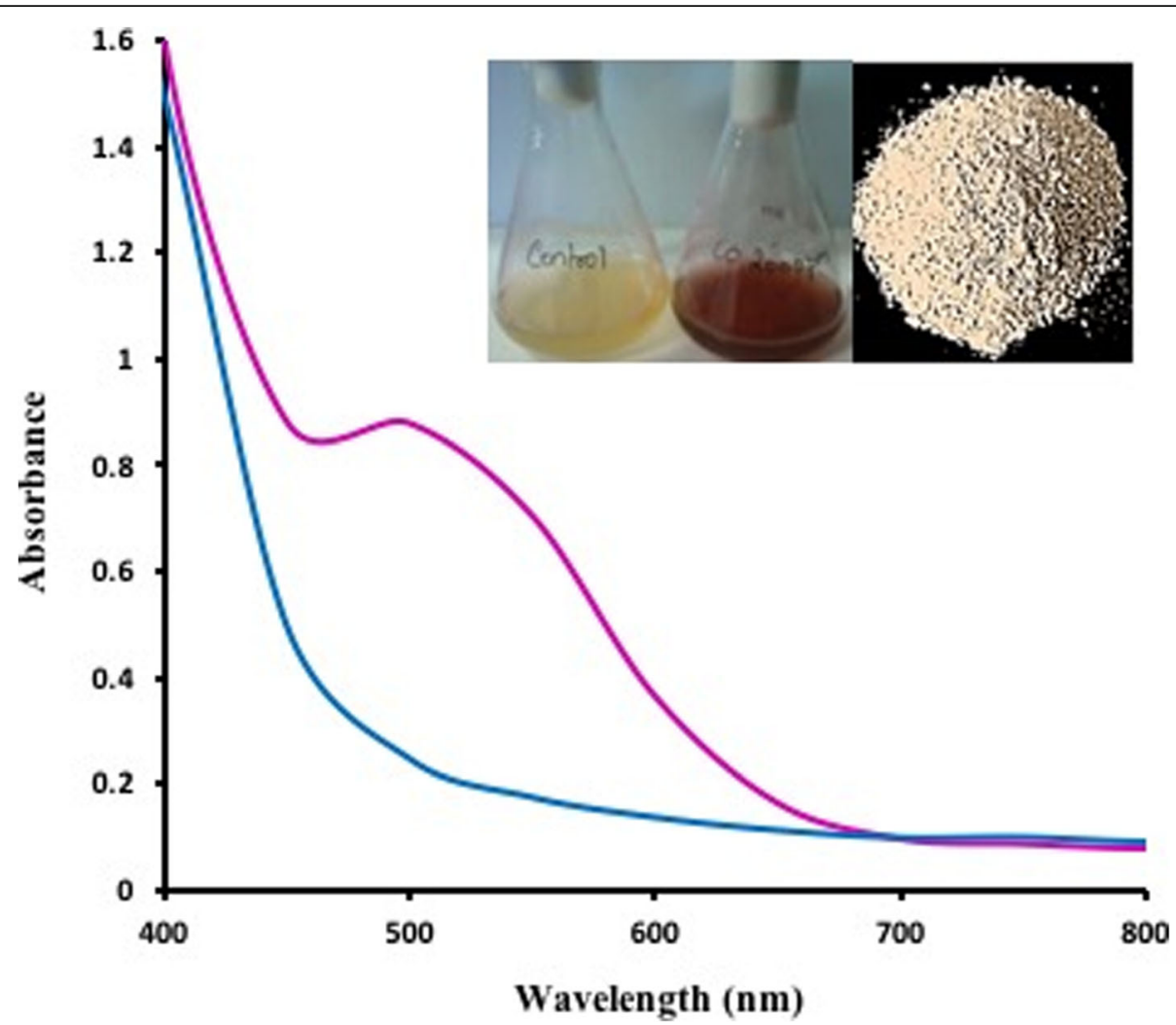

Fig. 2. UV-DRS absorption spectra of extracellular cobalt oxide nanoparticles $\left(\mathrm{CO}_{3} \mathrm{O}_{4}\right)$ synthesized by Microbacterium sp. MRS-1 incubated with $200 \mathrm{mg} / \mathrm{L}$ of $\mathrm{CoCl}_{2}$ at $37^{\circ} \mathrm{C}$ at $180 \mathrm{rpm}$ for $120 \mathrm{~h}$

peak around 450-600 $\mathrm{nm}$ which can be attributed to the formation of nanoparticles [25]. The presence of broad resonance indicated the evidence of aggregation of nanoparticles. Extracellularly synthesized cobalt oxide nanoparticles have been characterized by FT-IR, which is a very useful tool to investigate the interactions between bacterial cell wall components and cobalt ions.

\subsection{Microscopy}

Scanning electron microscopy showed uniform distribution of cobalt oxide nanoparticles. During elemental analysis of the synthesized nanoparticles, a high intense peak of oxygen was detected. The majority of the particles were uniformly spherical within the size range of $10-70 \mathrm{~nm}$. The elemental ratio of Co to $\mathrm{O}$ in the cobalt
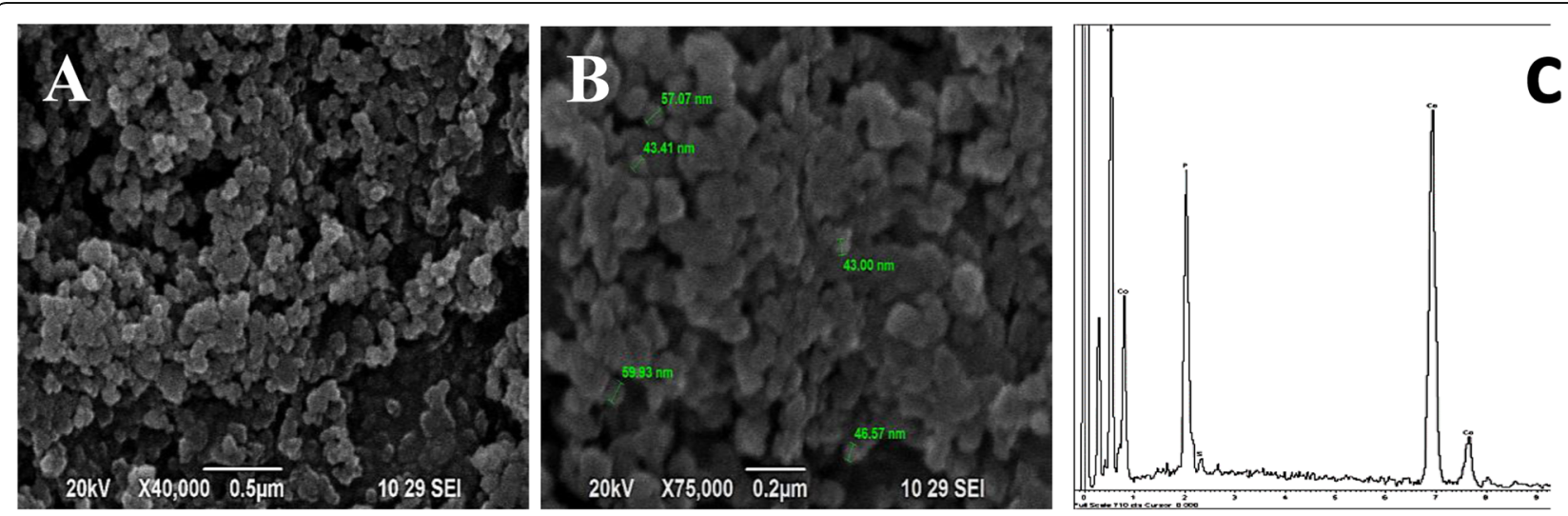

Fig. 3 Scanning electron microscopy $(\mathbf{a}, \mathbf{b})$ and (c) EDAX analysis of cobalt oxide nanoparticles $\left(\mathrm{Co}_{3} \mathrm{O}_{4}\right)$ synthesized by Microbacterium sp. MRS-1 treated with $200 \mathrm{mg} / \mathrm{L} \mathrm{CoCl}_{2}$. EDS spectrum recorded for the cobalt oxide nanoparticles with different X-ray emission peaks labeled. (Scale bar a $0.5 \mu \mathrm{m}, \mathbf{b} 0.2 \mu \mathrm{m})$ 
oxide nanoparticles is 54:34 (Fig. 3). In atomic force microscopic analysis, both spherical and pentagon-like cobalt oxide nanoparticles were observed in the range of 20-90 nm in size (Fig. 4). The XRD pattern of the cobalt oxide nanoparticles is shown in Fig. 5. All the diffraction peaks in the XRD can be indexed to cubic face centered $\mathrm{Co}_{2} \mathrm{O}_{3}$ and $\mathrm{Co}_{3} \mathrm{O}_{4}$. The peaks correspond to diffraction from (440), (622) planes showed good agreement with the JCPDS-pattern (JCPDS file no.: 02-1079) of $\mathrm{Co}_{2} \mathrm{O}_{3}$ and diffractions from (220), (311), (222), (400), (422), (511) planes showed good agreement with the JCPDSpattern (JCPDS file no.: 78-1969) of $\mathrm{Co}_{3} \mathrm{O}_{4}$. Comparison of JCPDS data confirms the formation of $\mathrm{Co}_{3} \mathrm{O}_{4}$ as the major fractions together with $\mathrm{Co}_{2} \mathrm{O}_{3}$ (Fig. 5).

\subsection{TGA}

The thermal gravimetric analysis of the synthesized cobalt nanoparticle showed gradual decomposition steps. Decomposition of cobalt nanoparticle was initiated at $100{ }^{\circ} \mathrm{C}$ at which, only about $7 \%$ of the decomposition was observed. The next stage of decomposition was observed at $225{ }^{\circ} \mathrm{C}$ where nearly about $15 \%$ of weight loss was observed, mass loss started at about $250{ }^{\circ} \mathrm{C}$ to 400 ${ }^{\circ} \mathrm{C}$ corresponding to $\sim 50 \%$ of the total mass. The reaction terminated in the range of $500-700{ }^{\circ} \mathrm{C}$ (Fig. 6). The FTIR spectra of the synthesized samples showed the evidence for the presence of an organic coating. The decomposition was observed in the TG analysis of cobalt nanoparticles could be due to the breakdown of the protein ligands.

\subsection{Tem}

Different TEM images revealed an average particle size and clearly observed the spherical and pentagon morphology of the synthesized cobalt oxide nanoparticles. Surface interactions between the synthesized cobalt oxide nanoparticles and bacterial cell wall were clearly observed and evidenced the aggregation of the nanoparticles based on TEM analysis. The aggregates were observed in the nutrient medium, and the TEM micrographs revealed the presence of particles in the range of 10-100 $\mathrm{nm}$ in size and the outer surface of the bacterial cell could be clearly observed (Fig. $7 \mathrm{a}-\mathrm{C}$ ). Cobalt oxide nanoparticles were bound on the cell wall at one pole of the bacteria under cobalt containing environment for $24 \mathrm{~h}$ (Fig. 7a). The accumulation of cobalt oxide nanoparticles all over the bacterial cell at $48 \mathrm{~h}$ can be clearly observed (Fig. 7b), and it is clearly seen that the cobalt nanoparticles were deposited as thick layer on the cell wall of the bacteria due to the prolonged exposure for about $72 \mathrm{~h}$ (Fig. 7c). Therefore, the isolated bacterial cells at the early stage of nanoparticles synthesis are rod shaped with smooth surfaces, but roughness of the surface developed during prolonged incubation.

\subsection{MTT assay}

Various metal oxides cytotoxicity by using 5-diphenyl tetrazolium bromide (MTT) assay has been widely demonstrated. The percentage cell viability of L929 cells were recorded at $24 \mathrm{~h}$ exposure of $\mathrm{Co}_{3} \mathrm{O}_{4}$-NPs. Cell viability at 50,75 , and $100 \mathrm{mg} / \mathrm{mL}$ of $\mathrm{Co}_{3} \mathrm{O}_{4}$-NPs exposed for $24 \mathrm{~h}$ were recorded as $100 \%, 84.5 \%$, and $47.83 \%$, respectively (Fig. 8). The increase in exposure of high concentration cobalt oxide nanoparticles at $50 \mathrm{mg} / \mathrm{ml}$ concentrations did not cause any decrease in cell viability, as the concentration of nanoparticle increased up to $100 \mathrm{mg} / \mathrm{mL}$ showed significant decrease in cell viability. The decrease in percentage of cell viability was $15 \%$ at
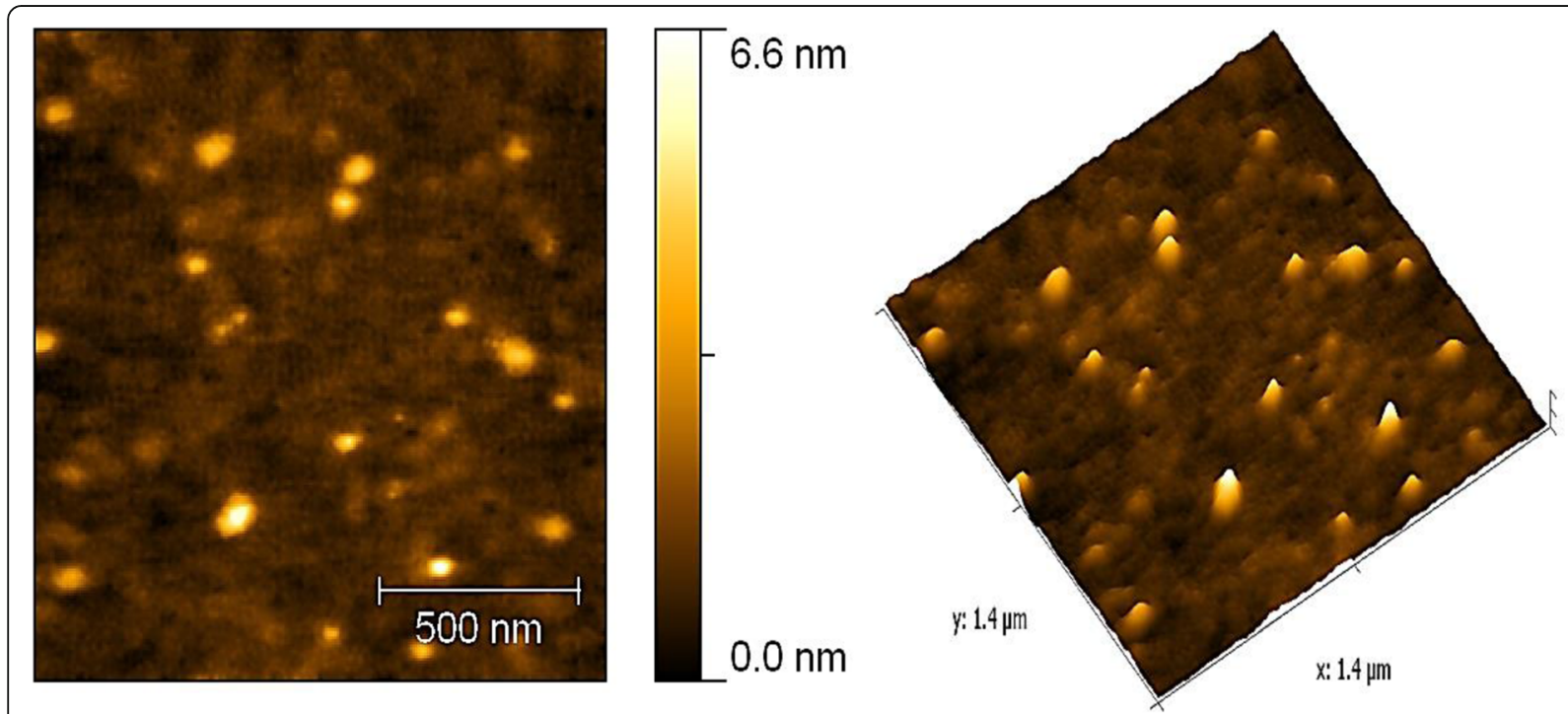

$6.6 \mathrm{~nm}$ $0.0 \mathrm{~nm}$

Fig. 4 Cobalt oxide nanoparticles $\left(\mathrm{CO}_{3} \mathrm{O}_{4}\right)$ synthesized by Microbacterium sp. MRS-1 treated with $\mathrm{CoCl}_{2}$ of $1 \mu \mathrm{m}$ field size. $1.4 \times 1.4 \mu \mathrm{m}$ 

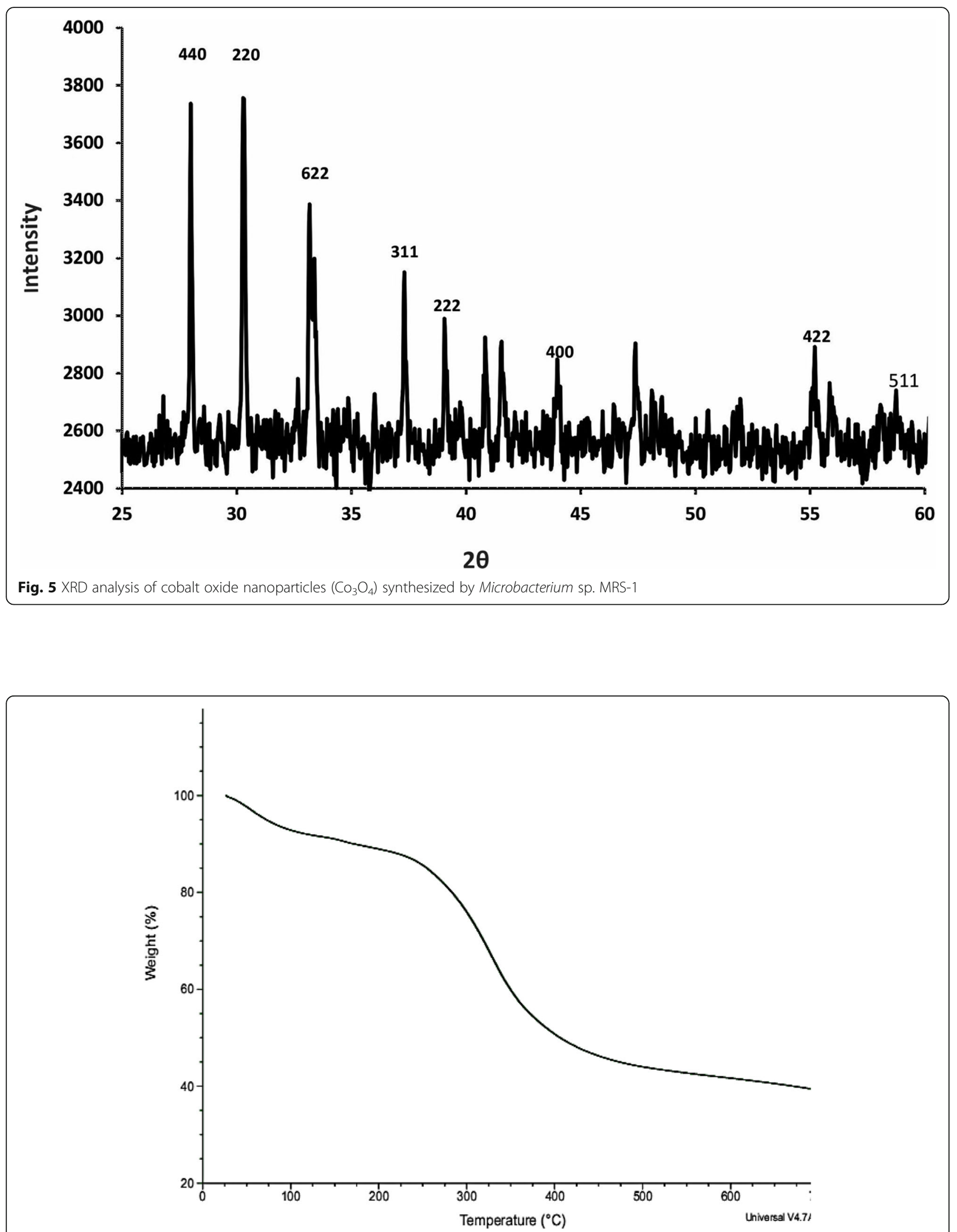

Fig. 6 Thermal gravimetric (TG) curve of bacterially (Microbacterium sp. MRS-1) synthesized cobalt oxide nanoparticles $\left(\mathrm{CO}_{3} \mathrm{O}_{4}\right)$ 

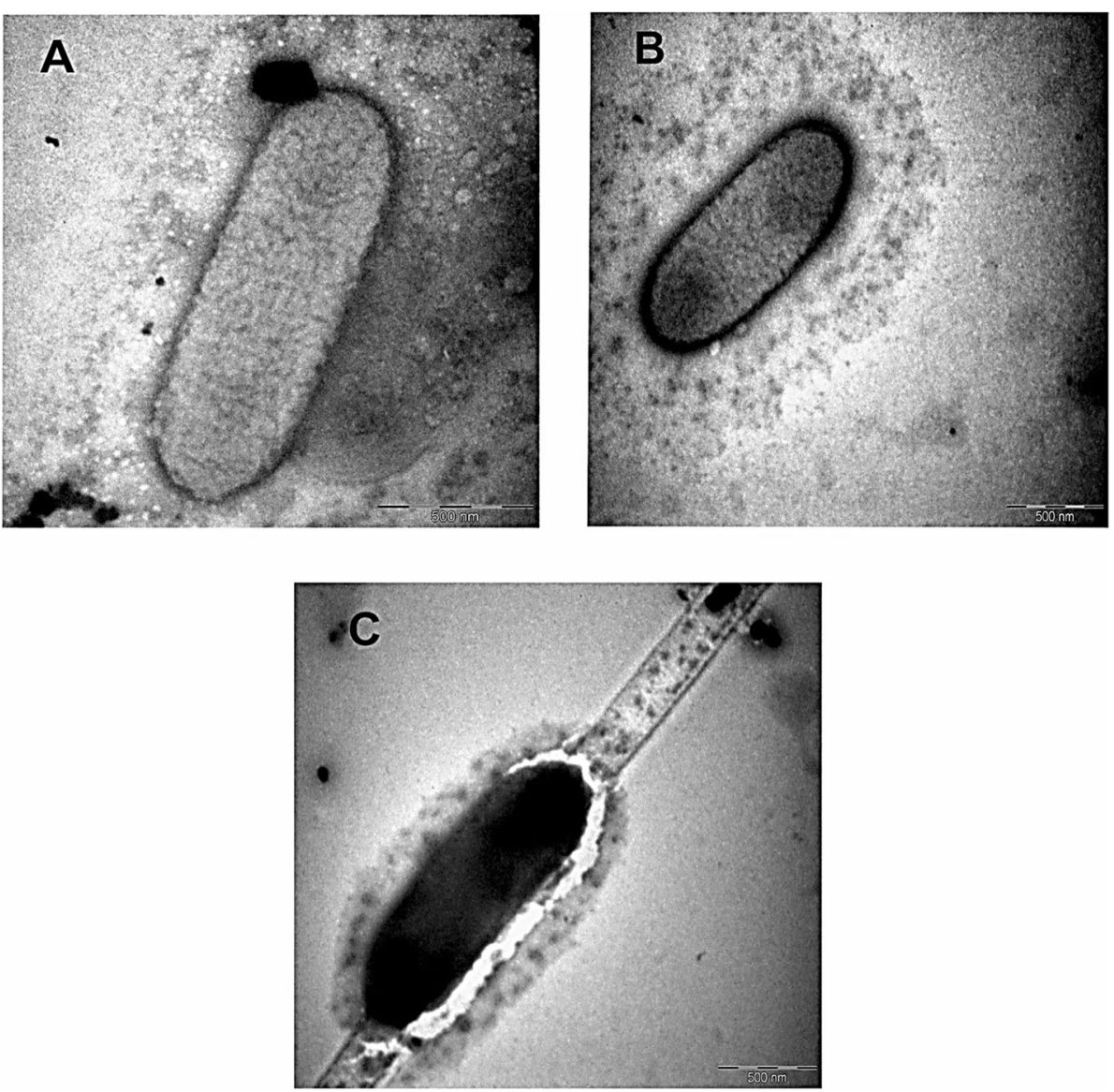

Fig. 7 Transmission electron micrograph of cobalt oxide nanoparticles $\left(\mathrm{CO}_{3} \mathrm{O}_{4}\right)$ synthesized using Microbacterium sp. MRS-1. a Large pentagon-like crystalline cobalt oxide nanoparticles were bound on the cell wall at one pole of the bacteria under cobalt containing environment for $24 \mathrm{~h}$. $\mathbf{b}$ Cobalt oxide nanoparticles $\left(\mathrm{CO}_{3} \mathrm{O}_{4}\right)$ were synthesized and accumulated all over the bacterial cell. Arrow indicates the synthesized cobalt nanoparticles around the bacterial cell, and it can be clearly seen that the cobalt nanoparticles were deposited as thick layer on the cell wall of the bacteria for $48 \mathrm{~h}$ to the metal environment. c Fully mineralized bacterium encrusted with cobalt oxide nanoparticles observed at $72 \mathrm{~h}$ of exposure to the metal environment

$75 \mathrm{mg} / \mathrm{ml}$ and approximately $50 \%$ decrease in cell viability at $100 \mathrm{mg} / \mathrm{mL}$ which showed concentration-based cytotoxicity at very minimum level when compared with previous cytotoxicity studies on nanoparticles.

\section{Discussion}

Extracellular production of less soluble cobalt oxide nanoparticles in the form of pale pink color powder has been observed in agreement with the previous reports for nanoparticle production using Geobacter sulfurreducens and Brevibacterium casei [26, 27]. FT-IR experiment was performed to study the functional groups of the cobalt nanoparticles. It showed absorption peak at $846 \mathrm{~cm}^{-1}$ which indicates the presence of $\mathrm{C}-\mathrm{H}$ bending vibration (data not shown). Also, it showed a sharp single peak at $694 \mathrm{~cm}^{-1}$, indicates the presence of optical vibrations of cobalt oxide which has been reported in the previous study [28]. From the surface topography of the cells incubated with cobalt chloride during 24 to 72 $\mathrm{h}$, we observe deformation in the cellular structure due to increasing exposure time to cobalt ions. It is reported that the deformation of the cells is a kind of stress response to protect themselves against high concentrations of metal ions [24]. Previous study showed that cobalt oxide $\left(\mathrm{Co}_{3} \mathrm{O}_{4}\right)$ nanoparticles exposure did produce cytotoxicity at the concentration of $25 \mu \mathrm{g} / \mathrm{mL}$ after $6 \mathrm{~h}$ in human small airway epithelial cells [29]. Obtained results showed that high exposure of biologically produced $\mathrm{Co}_{3} \mathrm{O}_{4}$ nanoparticles affects the cell viability at a very minimum level as revealed by cell viability assay.

\section{Conclusion}

The present study demonstrated the feasibility of Microbacterium sp. MRS-1 cells to synthesize extracellular cobalt oxide nanoparticles in powder form, while remediating cobalt in culture media. The extracellularly 


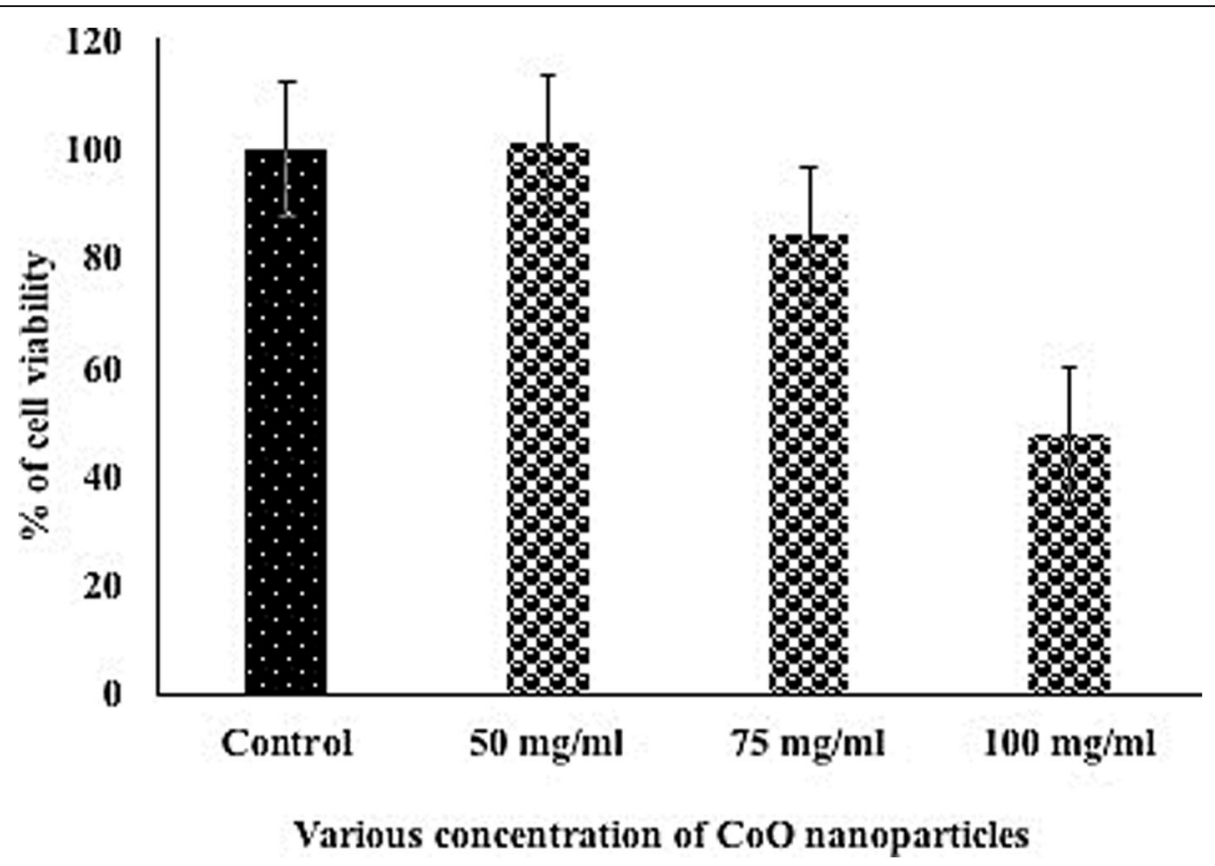

Fig. 8 MTT Assay-Percentage of cell viability $L 929$ cells were recorded at $24 \mathrm{~h}$ exposure of $\mathrm{CO}_{3} \mathrm{O}_{4}$-NPs. Cell viability at 50,75 , and 100 mg/mL of $\mathrm{CO}_{3} \mathrm{O}_{4}-\mathrm{NPs}$ exposed for $24 \mathrm{~h}$ with control cells without bacterially synthesized $\mathrm{CO}_{3} \mathrm{O}_{4}$ nanoparticles

synthesized cobalt oxide nanoparticles were easily recoverable and can be easily utilized for industrial applications as it has low level of cytotoxicity. This study provides the simple eco-friendly way to remediate environmental contamination of cobalt and the production of cobalt oxide nanoparticles for clinical and other industrial applications.

\begin{abstract}
Abbreviations
Co (II): Cobalt ions; $\mathrm{CoCl}_{2}$ : Cobalt chloride; $\mathrm{CO}_{3} \mathrm{O}_{4}$ : Cubic face-centered; NPs: Nanoparticles; UV-DRS: Ultraviolet-diffused reflection spectra; FTIR: Fourier transform infrared (FTIR) spectroscopy; XRD: X-ray diffraction; SEM: Scanning electron microscopy; TEM: Transmission electron microscopy; AAS: Atomic absorption spectroscopy; AFM: Atomic force microscopy; EDAX: Energy-dispersive $X$-ray spectroscopy; TGA: Thermogravimetric analysis; MTT: 3-(4,5-dimethylthiazol-2-yl)-2,5-diphenyltetrazolium bromide]; JCPDS: Joint Committee on Powder Diffraction Standards; C-H: Carbonhydrogen bond; $\mathrm{CO}_{2}$ : Carbon-dioxide; $\mathrm{d}_{2} \mathrm{O}$ : Distilled water; $\mathrm{H}$ : Hydrogen; DMEM: Dulbecco's modified Eagle's medium; FBS: Fetal bovine serum
\end{abstract}

\section{Acknowledgements}

The research grant provided by DST (DST/SSTP/ (TN)/09/64 DT.05.02.2010) for carrying out this study is gratefully acknowledged. S.S. acknowledges CSIR, New Delhi, for Senior Research Fellowship. The central facilities CAS, CEGS, NRCBS, IPLS, and PURSE in Madurai Kamaraj University are gratefully acknowledged. We thank Dr. Ramesh, TNVAS for electron microscopic analysis. We thank Karunya University for SEM-EDS, ITM-Chennai for XRD \& TGA analysis. Dr. Patrick Tang from the Department of Pathology, Sidra Medicine, Doha, Qatar, for the final review.

\section{Authors' contributions}

Sathyavathi Sundararaju (SS): planning, experiment performance, writing the manuscript. Manjula Arumugam (MA): performed few experiments, major corrections. Prakash Bhuyar (PB): provided valuable suggestions to improve the quality. All authors read and approved the final manuscript.
Funding

DST (DST/SSTP/ (TN)/09/64 DT.05.02.2010): CSIR, New Delhi for Senior Research Fellowship.

Availability of data and materials

Not applicable

Ethics approval and consent to participate

Not applicable

Consent for publication

Not applicable

Competing interests

No competing interest

\section{Author details}

'Department of Pathology, Sidra Medicine, Doha, Qatar. ${ }^{2}$ Department of Genetics, School of Biological Sciences, Madurai Kamaraj University, Madurai 625021, India. ${ }^{3}$ Algae Culture Collection Center \& Laboratory, Faculty of Industrial Sciences \& Technology, Universiti Malaysia Pahang, Lebuhraya Tun Razak, 26300 Gambang, Kuantan, Pahang, Malaysia.

Received: 20 January 2020 Accepted: 28 July 2020

Published online: 27 October 2020

\section{References}

1. Fernández-García M, Rodriguez JA (2011) Metal oxide nanoparticles Encyclopedia of inorganic and bioinorganic chemistry

2. Gouda M, Aljaafari A, Al-Fayz Y, Boraie WE (2015) Preparation and characterization of some nanometal oxides using microwave technique and their application to cotton fabrics. J Nanomater 16(1):163

3. Raman V, Suresh S, Savarimuthu PA, Raman T, Tsatsakis AM, Golokhvast KS, Vadivel VK (2016) Synthesis of Co3O4 nanoparticles with block and sphere morphology, and investigation into the influence of morphology on biological toxicity. Exp Ther Med 11(2):553-560

4. Kaviyarasu K, Raja A, Devarajan PA (2013) Structural elucidation and spectral characterizations of Co3O4 nanoflakes. Spectrochim Acta A Mol Biomol Spectrosc 114:586-591 
5. Diallo A, Beye AC, Doyle TB, Park E, Maaza M (2015) Green synthesis of Co3O4 nanoparticles via Aspalathus linearis: physical properties. Green Chem Lett Rev 8(3-4):30-36

6. Singh J, Dutta T, Kim KH, Rawat M, Samddar P, Kumar P (2018) Green'synthesis of metals and their oxide nanoparticles: applications for environmental remediation. J Nanobiotechnol 16(1):84

7. Naghdi, M., Taheran, M., Brar, S.K., Verma, M., Surampalli, R.Y. and Valéro, J.R (2015) Green and energy-efficient methods for the production of metallic nanoparticles. Beilstein J Nanotechnol 6(1):354-2376.

8. Gawali SR, Gandhi AC, Gaikwad SS, Pant J, Chan TS, Cheng CL, Ma YR, Wu SY (2018) Role of cobalt cations in short range antiferromagnetic co 304 nanoparticles: a thermal treatment approach to affecting phonon and magnetic properties. Sci Rep 8(1):249

9. Nidhin, M., Sreeram, K.J. and Nair, B.U (2012) Green synthesis of rock salt $\mathrm{CoO}$ nanoparticles for coating applications by complexation and surface passivation with starch. Chem Eng J 185:352-357.

10. Gadd GM (2000) Bioremedial potential of microbial mechanisms of metal mobilization and immobilization. Curr Opin Biotechnol 11:271-279

11. Wu, H., Liu, G., Wang, X., Zhang, J., Chen, Y., Shi,J., Yang, H., Hu, H., Yang, S (2011) Solvothermal synthesis of cobalt ferrite nanoparticles loaded on multiwalled carbon nanotubes for magnetic resonance imaging and drug delivery, Acta Biomater 7(9):3496-3504.

12. Pita M, Abad JM, Vaz-Dominguez C, Briones C, Mateo-Martí E, Martín-Gago JA, Fernández VM (2008) Synthesis of cobalt ferrite core/metallic shell nanoparticles for the development of a specific PNA/DNA biosensor. J Colloid Interface Sci 321(2):484-492

13. Hasanzadeh M, Karim-Nezhad G, Shadjou N, Hajjizadeh M, Khalilzadeh B, Saghatforoush L, Ershad S (2009) Cobalt hydroxide nanoparticles of some amino acids, modified glassy carbon electrode as a biosensor for electrooxidation and determination, anal. Biochem. 389(2):130-137

14. Salvadori MR, Nascimento CAO, Corrêa B (2014) Nickel oxide nanoparticles film produced by dead biomass of filamentous fungus. Sci Rep 4:6404

15. Ozkaya T, Baykal A, Toprak MS, Koseoglu Y, Durmuş Z (2009) Reflux synthesis of $\mathrm{Co} 3 \mathrm{O} 4$ nanoparticles and its magnetic characterization. J Magn Magn Mater 321:2145-2149

16. Sathyavathi S, Manjula A, Rajendhran J, Gunasekaran P (2014) Extracellular synthesis and characterization of nickel oxide nanoparticles from microbacterium sp. MRS-1 towards bioremediation of nickel electroplating industrial effluent. Bioresour Technol 165:270-273

17. Narayanan, K.B and Sakthivel, N (2010) Biological synthesis of metal nanoparticles by microbes, Adv Colloid Interf Sci 156:1-13.

18. Abou-Shanab RAl, Van Berkum P, Angle JS (2007) Heavy metal resistance and genotypic analysis of metal resistance genes in gram-positive and gram-negative bacteria present in Ni-rich serpentine soil and in the rhizosphere of Alyssum murale. Chemosphere. 68:360-367

19. Aniszewski E, Peixoto RS, Mota FF, Leite SGF, Rosado AS (2010) Bioemulsifier production by microbacterium sp. strains isolated from mangrove and their application to remove cadmium and zinc from hazardous industrial residue. Braz J Microbiol 41:235-245

20. Wang C, Singh P, Kim YJ, Mathiyalagan R, Myagmarjav D, Wang D et al (2016) Characterization and antimicrobial application of biosynthesized gold and silver nanoparticles by using microbacterium resistens. Artif Cells Nanomed Biotechnol 44(7):1714-1721

21. Yang, S., Cui, G., Pang, S., Cao, Q., Kolb, U., Feng, X., \&..K. Müllen, K (2010) Fabrication of cobalt and cobalt oxide/graphene composites: towards highperformance anode materials for lithium ion batteries, ChemSusChem. 3(2): 236-239.

22. Kumar U, Shete A, Harle AS, Kasyutich O, Schwarzacher W, Pundle A, Poddar P (2008) Extracellular bacterial synthesis of protein-functionalized ferromagnetic Co3O4 nanocrystals and imaging of self-organization of bacterial cells under stress after exposure to metal ions. Chem Mater 20: 1484-1491

23. Khan I, Saeed K, Khan I (2017) Nanoparticles: properties, applications and toxicities. Arab J Chem

24. Pant AB, Agarwal AK, Sharma VP, Seth PK (2001) In vitro cytotoxicity evaluation of plastic biomedical devices. Human Exp Toxicol 20(8):412-417

25. Coker VS, Telling ND, van der Laan G, Pattrick RA, Pearce Cl, Arenholz E, Lloyd JR (2009) Harnessing the extracellular bacterial production of nanoscale cobalt ferrite with exploitable magnetic properties. ACS Nano 3:1922-1928

26. Kumar U, Vivekanand K, Poddar P (2009) Real-time Nanomechanical and topographical mapping on live bacterial cells Brevibacterium casei under stress due to their exposure to $\mathrm{Co} 2+$ ions during microbial synthesis of Co3O4 nanoparticles. J Phys Chem B 113:7927-7933

27. Farhadi S, Javanmard M, Nadri G (2016) Characterization of cobalt oxide nanoparticles prepared by the thermal decomposition. Acta Chim Slov 63(2):335-343

28. Sufi RA, Kofinas P (2005) Magnetic properties and morphology of block copolymer cobalt oxide nanocomposites. J Magnetism Magnetic Mater 288: 219-223

29. Sisler JD, Pirela SV, Shaffer J, Mihalchik AL, Chisholm WP, Andrew ME, Schwegler-Berry D, Castranova V, Demokritou P, Qian Y (2016) Toxicological assessment of $\mathrm{CoO}$ and La2O3 metal oxide nanoparticles in human small airway epithelial cells. Toxicol Sci 150(2):418-428. https://doi.org/10.1093/ toxsci/kfw005

\section{Publisher's Note}

Springer Nature remains neutral with regard to jurisdictional claims in published maps and institutional affiliations.

\section{Submit your manuscript to a SpringerOpen ${ }^{\circ}$ journal and benefit from:}

- Convenient online submission

- Rigorous peer review

- Open access: articles freely available online

High visibility within the field

- Retaining the copyright to your article

Submit your next manuscript at $>$ springeropen.com 